\title{
Extrakce trombů zlepšuje prognózu u pacientů s akutním infarktem myokardu
}

\author{
Stanislav Šimek, Jan Horák, Jan Bělohlávek, Tomáš Kovárník, Jiří Humhal, Vít Řezníček, Michael Aschermann \\ 2. interní klinika kardiologie a angiologie, Všeobecná fakultní nemocnice a 1. lékařská fakulta Univerzity Karlovy, Praha, Česká republika
}

Adresa: MUDr. Stanislav Šimek, CSc., FESC, 2. interní klinika kardiologie a angiologie, VFN a 1. LF UK, U nemocnice 2, 12800 Praha 2, Česká republika, e-mail: ssime@lf1.cuni.cz

Nejčastější př́ičinou akutního infarktu myokardu (AIM) je uzávěr koronární tepny trombem. Tento objev před třiceti lety ${ }^{(1)}$ umožnil začít s kauzální léčbou infarktu. Tehdy revoluční reperfuzní fibrinolytická terapie byla posléze překonána účinnější a spolehlivější léčbou intervenční. Primární perkutánní koronární intervence (PCI), s cílem obnovit normální průtok infarktovou tepnou do $90 \mathrm{~min}$ od stanovení diagnózy AIM, se stala metodou volby všude tam, kde je dostupná. Při klasické primární PCI je trombotický uzávěr nejprve překonán flexibilním koronárním vodičem a posléze je krátkou balonkovou dilatací nebo prrímou implantací stentu normalizován koronární průtok.

Vyvstává otázka, co se stane s koronárním trombem po mechanickém rozrušení balonkem nebo stentem během primární PCI. Je-li trombus malý, může se teoreticky rychle rozpustit za přispění současné antikoagulační a antiagregační léčby. Druhou možností je přitlačení k cévní stěně a fixace trombu v původní pozici implantovaným stentem. Tento mechanismus se předpokládá zejména $\mathrm{v}$ případě, pokud je stent implantován přímo bez balonkové predilatace. Nejpravděpodobněji se však trombus během PCI uvolní a embolizuje do periferie koronární tepny. Je jen otázkou, jak je trombus velký, kde se zastaví a do jaké míry uzavře nebo neuzavře některou část povodí infarktové tepny; záleží také, jak je toto povodí velké. Může dojít $\mathrm{k}$ pouze neviditelné mikroembolizaci s následným zpomalením distálního průtoku, tzv. „slow flow“, nebo ke kompletnímu zastavení průtoku, tzv. „no flow“. Výsledkem je nekompletní reperfuze, která se zpravidla projeví přetrváváním ischemických změn na EKG či zpomaleným vymýváním kontrastu z infarktového ložiska („blush“). Nemocní s distální embolizací mají enzymaticky větší infarkty a nižší ejekční frakci levé komory. Co je však nejdůležitější, významně horší je také dlouhodobá mortalita. ${ }^{(2)}$ Například v práci Henriquese a spol. byl během pětiletého sledování rozdíl mortality $44 \%$ vs. $9 \%(p<0,001)$, viz obrázek $1 .{ }^{(3)}$
Velké embolizace během primární PCI, s následkem dramatického omezení průtoku ošetřenou tepnou, naštěstí nejsou časté. Přesto každý intervenční kardiolog několikrát zažil zklamání, kdy se mu nejprve podařilo obnovit normální krevní průtok v infarktové tepně vodičem, popř. balonkem, a kdy po implantaci stentu došlo k zastavení průtoku, často provázenému zhoršením stavu pacienta. Př́činou je většinou právě embolizace trombu vytěsněného stentem ze své pozice. $\mathrm{V}$ př́padě trombózy blízko ostia koronární tepny může dojít také k uvolnění trombu do aorty a $\mathrm{v}$ horším prúpadě do mozkových tepen.

Frekvence i důsledky distální embolizace během primární PCI se u různých autorů liší. Henriquese a spol. ve své práci publikované v roce 2002 zjistili viditelnou distální embolizaci u 15,2 \% pacientů. Její dopad na zhoršení pětileté mortality byl dramatický, viz obrázek $1 .^{(3)} \mathrm{V}$ novější publikaci z roku 2009 byl výskyt viditelné embolizace po primární PCI zjištěn pouze u $6,3 \%$ pacientů s jen nevýznamným zvýšením roční mortality: 7,1 \% vs. 5,2 \%. ${ }^{(4)}$ Příčinou příznivějších výsledků v novější studii je pravděpodobně použití trojkombinační antiagregační léčby (kyselina acetylsalicylová, clopidogrel, inhibitor GP IIb/IIIa), která je jednou z možností, jak riziko a následky distální embolizace snížit. Představě, že protidestičková léčba může př́znivě ovlivnit riziko distální embolizace a zlepšit myokardiální perfuzi, odpovídají i výsledky metaanalýzy studií, které testovaly účinek inhibitoru GP IIb/IIIa abciximabu u nemocných se STEMI. Použití abciximabu před primární PCI zde snížilo 30denní i dlouhodobou mortalitu pacientů zhruba o $30 \%,{ }^{(5)}$ tato léčba by se měla rutinně používat.

Z výše uvedeného vyplývá, že významná část našich pacientů se STEMI léčených primární PCI má navzdory úspěšné reperfuzi epikardiálních arterií persistující poruchu mikrovaskulární perfuze. Následkem je kromě většího rozsahu infarktu také predispozice $\mathrm{k}$ arytmiím, srdečnímu 


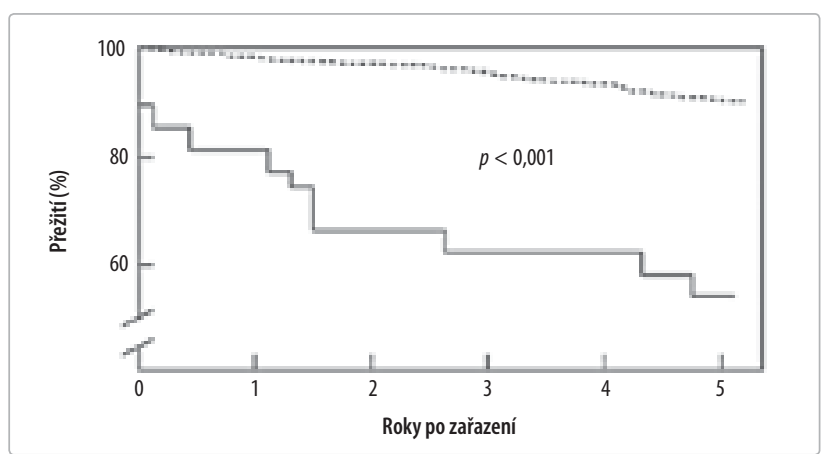

Obrázek 1 Dlouhodobé přežívání pacientů bez embolizace

(----) s distální embolizací, (-) během primární $\mathrm{PC|}{ }^{(3)}$

selhání, kardiogennímu šoku a smrti. Na tomto místě je nutno zmínit, že někdy je obtížné určit, zda mikrovaskulární poruchy, popř. pomalý průtok infarktovou tepnou, jsou způsobeny pouze distální embolizací, nebo zda příčinou je již pokročilá nekróza myokardu a s ní související myokardiální perivaskulární edém. Přesto je nanejvýš logická snaha najít metodu, která by riziko distální embolizace během primární PCI minimalizovala. $\mathrm{K}$ tomuto účelu byla vyvinuta řada mechanických antiembolických systémů, které lze $\mathrm{v}$ zásadě rozdělit na:

> systémy manuální trombektomie, tj. trombaspirace

> systémy mechanické trombektomie

> systémy distální ochrany

> systémy tromboablace

> kryté stenty

> systémy proximální ochrany

Manuální trombektomie nazývaná také trombaspirace se provádí speciálním, k tomu určeným dutým katetrem (Export, Pronto, Diver, Fetch, Rescue, TVAC), který se zavádí stejně jako balonkový PCI katetr po koronárním vodiči do trombu, viz obrázky $2 a$ a $2 b$. Aspirace se provádí prostým nasátím do injekční stříkačky. Použití je pro operatéra velmi jednoduché. Odsátí trombů se obvykle provádí 2-5krát podle dosaženého účinku a v závislosti na velikosti trombu. Výhodou této techniky je kromě jednoduchosti také relativně nízká cena. Vzhledem $\mathrm{k}$ tomu, že v naprosté většině případů lze po odsátí trombů implantovat stent, a trombaspirační katetr tak vlastně nahradí kate-

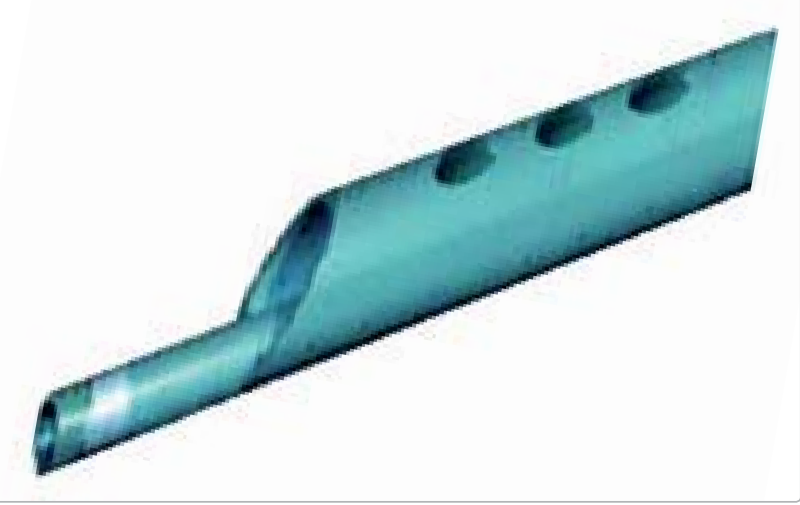

Obrázek 2a Manuální trombektom

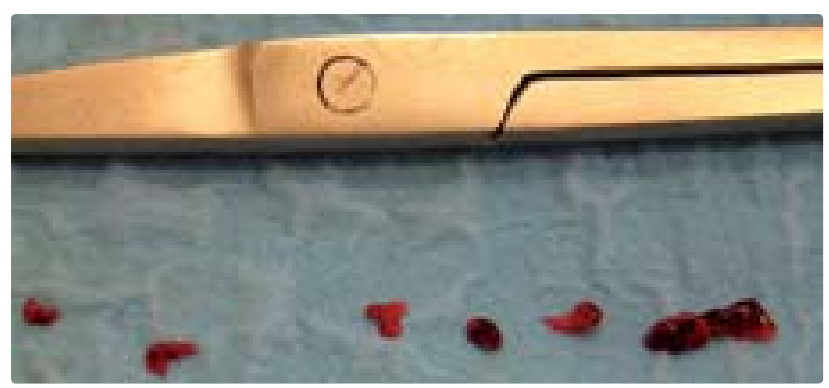

Obrázek 2b Tromby získané manuální trombektomií

tr balonkový, nepředstavuje metoda žádné mimořádné náklady. Také časové zdržení je malé - závisí na počtu aspirací. $\mathrm{V}$ některých prrípadech je po odsátí trombu nález na koronární tepně normální a stent není vůbec třeba implantovat, viz obrázky $3 a$ a $3 b$. Množství odsáté krve je asi $30 \mathrm{ml}$ při každé aspiraci, takže celkové množství krevní ztráty může být 150 i více $\mathrm{ml}$.

Mechanické trombektomy využívají k rozrušení a odsátí trombů rotující katetry nebo rychlý proud fyziologického roztoku (AngioJet, X-sizer). V prrípadě katetru X-sizer se do koronární tepny zavádí rotující turbínka, která podobně jako mixér rozmělňuje trombus a zároveň jej vhání do katetru a ven $z$ těla, viz obrázek 4. Systém AngioJet využívá Bernoulliho účinku, kdy voda proudící v katetru vysokou rychlostí směrem proximálně vytváří podtlak, nasává trombotický materiál, a unáší jej z koronární tepny, viz obrázek 5. Nevýhodou těchto systémů jsou poněkud větší rozměry a menší flexibilita katetrů, které vyžadují silnější instrumentárium a snižující použitelnost ve vinutých koronárních tepnách. Katetry je nutno připojit k vnější pohonné jednotce, což činí proceduru technicky náročnější.

Systémy distální protekce (GuardWire, FilterWire, SpideRX, Angioguard) se zavádějí na vlastním vodiči distálně za místo trombu ještě před dilatací balonku. Systém Guar-Wire využívá okluzivního balonku, který se odstraní až

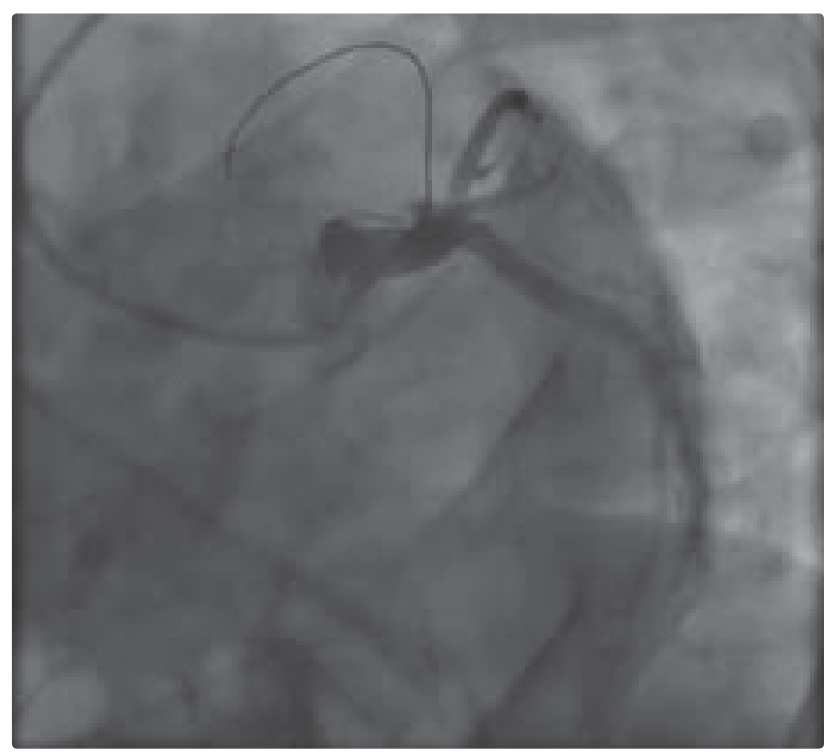

Obrázek 3a Uzávěr RIA u nemocného s předním infarktem myokardu

RIA - ramus interventricularis anterior 


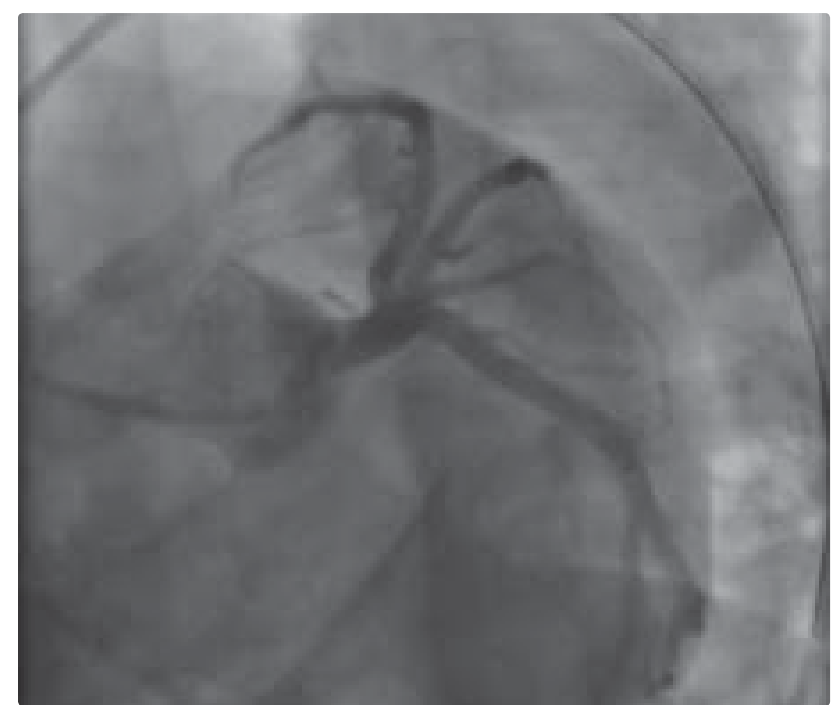

Obrázek 3b Nález po trombaspiraci je optimální a nevyžaduje další intervenci

po ukončení intervence a odsátí krve z místa uzávěru. Ostatní systémy využívají speciálních filtrů, které zachytávají uvolněné tromby a posléze jsou vtaženy do katetru.

Systémy tromboablace odstraňují trombus působením laseru nebo ultrazvuku. Kryté stenty jsou na své abluminální straně pokryty mikroporézní tkaninou. V místě implantace kompletně pokrývají cévní stěnu, snižují tím riziko uvolnění trombu přes oka stentu. Systémy proximální ochrany zabraňují embolizaci trombů tím, že okludují intervenovanou tepnu proximálně nad uzávěrem a umožňuji tak následné odsátí dříve, než k embolizaci dojde. Ve srovnání s distální ochranou se nevyžaduje zavedení přes trombus s rizikem embolizace. Jejich význam, stejně jako význam krytých stentů je nutno teprve zjistit. ${ }^{(6)}$

Až do současné doby randomizované studie s trombektomií a distální ochranou u pacientů se STEMI přinášely kontroverzní výsledky. Některé studie uváděly pozitivní vliv na dynamiku úseku ST na EKG, na rychlost koronárního průtoku nebo na vymývání kontrastu z myokardu po PCI. Zásadním problémem použití antiembolizačních metod však byla po dlouhou dobu neschopnost prokázat pozitivní účinek na prognózu pacientů. Jednou z větších studií byla např́iklad studie AiMI, která randomizovala 480

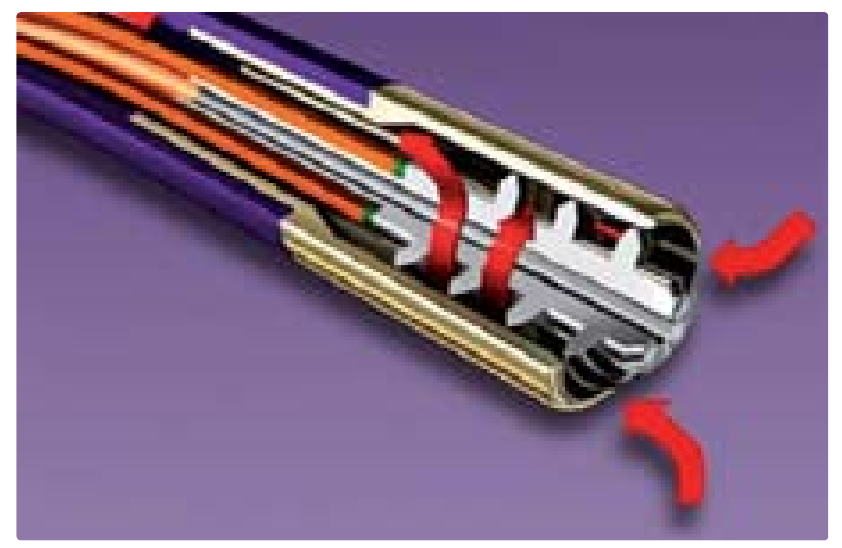

Obrázek 4 Mechanický trombektom X-sizer pacientů se STEMI k použití systému AngioJet, nebo k standardní primární PCI. Hlavním sledovaným parametrem byla velikost infarktu hodnocená pomocí SPECT vyšetření. Ukázalo se, že nemocní léčení trombektomií měli infarkt myokardu signifikantně větší. Navíc, měli také vyšší třicetidenní mortalitu $(4,6 \%$ vs. $0,8 \%, p \leq 0,02) .{ }^{(7)}$ Podobné výsledky přinesla i randomizovaná studie X-AMINE, která testovala mechanický trombektom X-sizer na souboru 200 pacientů se STEMI. Mezi léčenými skupinami sice nebyl významný rozdíl v počtu kardiovaskulárních př́íhod, nicméně u pacientů po trombektomii byla pozorována dvakrát vyšší mortalita. ${ }^{(8)}$ Výsledky studií s manuální trombektomií byly dlouho také rozporuplné. Další pozornost si zaslouží i v některých studiích zjištěné hraničně vyšší riziko cévní mozkové prríhody při použití trombaspirace. ${ }^{(9-11)}$

V roce 2007 publikovali De Luca a spol. metaanalýzu 21 provedených randomizovaných studií, které testovaly různé mechanické antiembolizační techniky u pacientů s akutním infarktem myokardu. Zařazeno bylo celkem 3721 pacientů. Po použití antiembolizační léčby byl častěji pozorován normální průtok TIMI 3 infarktovou tepnou (89,4 \% vs. $87,1 \%, p=0,03)$, normální vymývání kontrastu - „blush“ 3 (48,8 \% vs. $36,5 \%, p<0,0001)$ a méně distálních embolizací (6,0\% vs. 9,3\%,p=0,008). Třicetidenní mortalita však nebyla v této analýze antiembolizační léčbou ovlivněna $(2,5 \%$ vs. $2,6 \%, p=0,88) .{ }^{(12)}$ Prakticky stejné výsledky přinesla metaanalýza studií, kterou ve stejném roce publikoval Babu Kunadian. ${ }^{(13)}$ Také metaanalýza zahrnující 3180 pacientů se STEMI, publikovaná ještě v lednu 2008, zjistila, že mechanická antiembolická léčba přináší sice méně identifikovatelné distální embolizace - HR 0,54 (95\% CI 0,37-0,81), nižší výskyt zpomaleného koronárního průtoku TIMI < 3 - HR 0,53 (0,37-0,76) i zpomaleného vymývání kontrastu MBG < 3 - HR 0,60 (0,45-0,78). Výskyt kardiovaskulárních prríhod však opět nebyl ovlivněn. ${ }^{(14)}$

Situace se výrazně změnila po publikování výsledků přelomové studie TAPAS (The Thrombus Aspiration during Percutaneous coronary intervention in Acute myocardial infarction Study). Pacienti se STEMI, v počtu 1071 , byli do 12 hodin randomizováni bud' k iniciální trombaspiraci

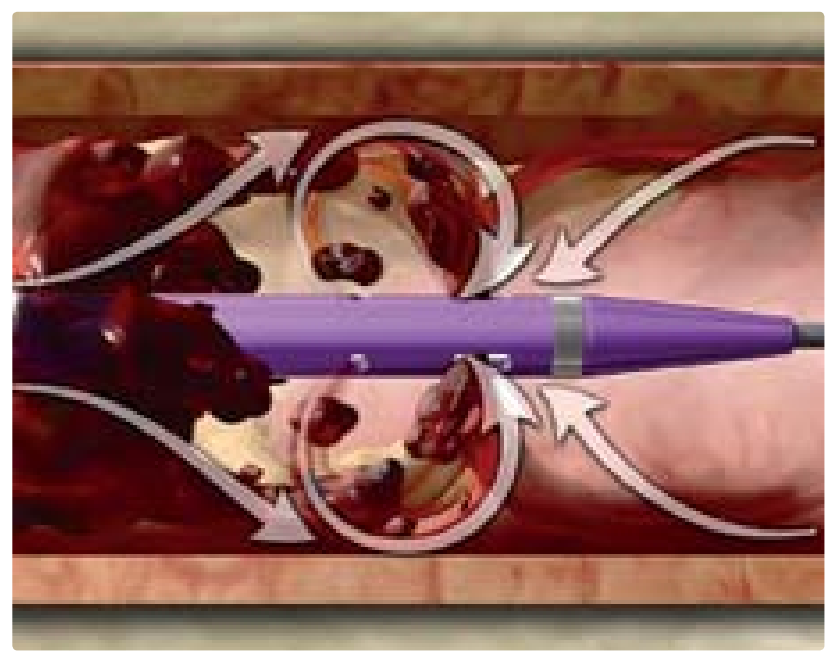

Obrázek 5 Mechanický trombektom AngioJet 
s následnou implantací stentu, nebo ke konvenční primární PCI s použitím balonku a stentu. Všichni byli zároveň léčeni trojkombinační antiagregační léčbou. Histopatologickým vyšetřením aspirátů byla zjištěna přítomnost většinou destičkových trombů v $73 \%$. Pro hodnocení vlivu léčby na distální perfuzi byl použit vývoj úseku ST na EKG a myokardiální „blush“ (rychlost vymývání kontrastu) po intervenci. Ukázalo se, že kompletní ústup elevací úseku ST na EKG je významně častější ve skupině pacientů, kterým byla provedena trombaspirace $(56,6 \%$ vs. $44,2 \%, p<0,001)$. Patologický „blush“ 0 nebo 1 byl přítomen méně často v léčené skupině $(17,1 \%$ vs. $26,3 \%, p<0,001)$. Třicetidenní mortalita i výskyt ostatních kardiovaskulárních příhod byly významně vyšší u pacientů s persistující poruchou distální perfuze „blush“ 0 nebo 1 . Mortalita podle skóre „blush“ 0 nebo 1,2 a 3 byla 5,2 \%, 2,9\%, resp. 1,0\% $(p=0,003)$. ${ }^{(15)}$ Největším překvapením studie TAPAS však byly výsledky ročního sledování. Ukázalo se, že ti nemocní, u nichž byla provedena trombaspirace, mají nižší roční mortalitu 3,6 \% vs. $6,7 \%$ (HR 1,93, 95\% CI 1,11-3,37, $p=0,020)$, viz obrázek 6; i nižší výskyt kardiální smrti společně s infarktem $5,6 \%$ vs. 9,9 \% (HR 1,81; 95\% CI 1,16-2,84; $p=0,009$ ). ${ }^{(16)}$

Výsledky analýzy podskupin ve studii TAPAS ukázaly, že z trombaspirační léčby mají prospěch pacienti - muži i ženy, staří i mladí, nemocní z proximálními i distálními uzávěry koronárních tepen, nezávisle na stupni průtoku před intervencí. Byl patrný trend $\mathrm{k}$ lepšímu účinku trombaspirace u pacientů s ischemickým časem pod $180 \mathrm{~min}$, viz obrázek 7. Důležité je, že účinek trombaspirace byl nezávislý na tom, zda byl či nebyl při iniciální angiografii viditelný trombus. Odpovídá to představě, že trombus je v infarktové tepně prítomen prakticky vždy. Hovoři to pro použití trombaspirace při každé primární PCI, pokud je schůdná.

Při hodnocení výsledků studie TAPAS je třeba uvést, že se jednalo o práci pouze $\mathrm{z}$ jednoho univerzitního pracoviště, kde lze předpokládat nadprůměrnou zkušenost provádějících intervenčních kardiologů s velmi vysokou procedurální úspěšností. Existují určité pochybnosti, zda při širokém použití metody lze očekávat stejně dobré výsledky. Existuje jistá obava, že zavádění trombaspiračního katetru může v některých případech způsobit disekci nebo i jinak poškodit stěnu arterie s následnou nutností použití delších stentů s vyšším rizikem restenózy. Z některých zkušeností

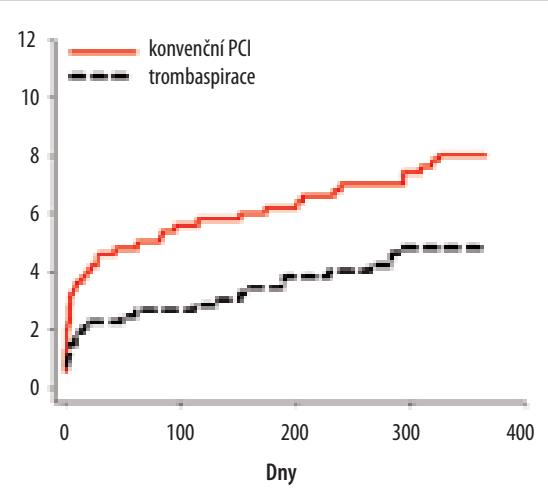

Obrázek 6 Roční mortalita ve studii TAPAS ${ }^{(16)}$ vyplývá, že direktní stenting bez předchozí balonkové dilatace snižuje riziko distální embolizace. Ve studii TAPAS byl $\mathrm{u}$ většiny pacientů $\mathrm{v}$ trombaspirační skupině proveden direktní stenting, zatímco ve skupině konvenční PCI byla $\mathrm{u}$ většiny provedena nejprve balonková angioplastika. To mohlo zvýšit frekvenci distální embolizace v konvenční skupině PCI a ovlivnit výsledky ve prospěch trombaspirace.

Výsledky studie TAPAS podpořila i zatím poslední publikovaná randomizovaná studie EXPIRA (Thrombectomy with Export Catheter in Infarct-Related Artery during primary percutaneous coronary intervention). Na souboru 175 pacientů bylo zjištěno, že manuální trombaspirace zlepšuje myokardiální „blush“, zrychluje ústup ischemických změn EKG a snižuje velikost infarktu. Během devítiměsíčního sledování měli nemocní po trombaspiraci významně nižší mortalitu $(4,6 \%$ vs. $0 \%, p=0,02) .^{(11)}$

Díky studii TAPAS se změnily závěry nově provedených metaanalýz. Poté co De Luca a spol. zahrnuli TAPAS do své metaanalýzy, získali soubor 2417 pacientů se STEMI, randomizovaných $\mathrm{v}$ devíti studiích $\mathrm{k}$ manuální trombektomii nebo ke standardní primární PCI. Zjistili opět, že u nemocných po trombaspiraci je častěji pozorován postprocedurální normální průtok TIMI III infarktovou tepnou ( $87,1 \%$ vs. $81,2 \%, p<0,0001)$ i normální perfuze myokardu MBG 3 (myocardial blush grade 3) (52,1 \% vs. 31,7 \%, $p<0,0001)$. Trombaspirací se významně snížil výskyt distální embolizace (7,9\% vs. 19,5\%; $p<0,0001)$, ale hlavně také 30denní mortalita $(1,7 \%$ vs. $3,1 \%, p=0,04) .{ }^{(17)}$ Bavry a spol. ve stejné době, tj. v říjnu 2008, publikovali další metaanalýzu třiceti randomizovaných studií, které testovaly různé systémy $\mathrm{k}$ prevenci distální embolizace během primární PCI, provedené do 12 hodin po vzniku akutního infarktu myokardu. Na souboru 6415 pacientů zjistili, že vliv na mortalitu závisí na typu použité metody. Zatímco trombaspirační systémy snižují mortalitu (2,7 \% vs. $4,4 \%$, $p<0,018$ ) [potřebný počet léčených na záchranu jednoho života $=59$ ], mechanické trombektomy naopak mortalitu spíše zvyšují (5,3 \% vs. 2,8 \%,p<0,05), tj. způsobí jednu smrt navíc léčbou 38 pacientů. Systémy distální protekce (filtry a okluzivní balonky) mají v této analýze vliv na mortalitu neutrální.

\section{Závěr}

Akutní infarkt myokardu se v civilizovaných zemích výrazně podílí na populační mortalitě. Nevídané snížení mortality, dosažené použitím manuální trombaspirace ve studiích TAPAS a EXPIRA, může mít tedy velmi výrazný celospolečenský dopad. Závěry studie TAPAS i následných metaanalýz, pokud se potvrdí, mohou mít rozsáhlé výstupy ve smyslu doporučení rutinního užití trombaspirace u většiny nemocných se STEMI. Uvedené závěry je třeba ještě ověřit dalšími velkými studiemi, nicméně již dnes lze rutinní používání manuální trombaspirace během primární PCI doporučit u většiny pacientů, pokud to anatomické podmínky dovolí. $\mathrm{Na}$ řadě tuzemských intervenčních pracovištł se již trombaspirace rutinně používá. Naopak, 


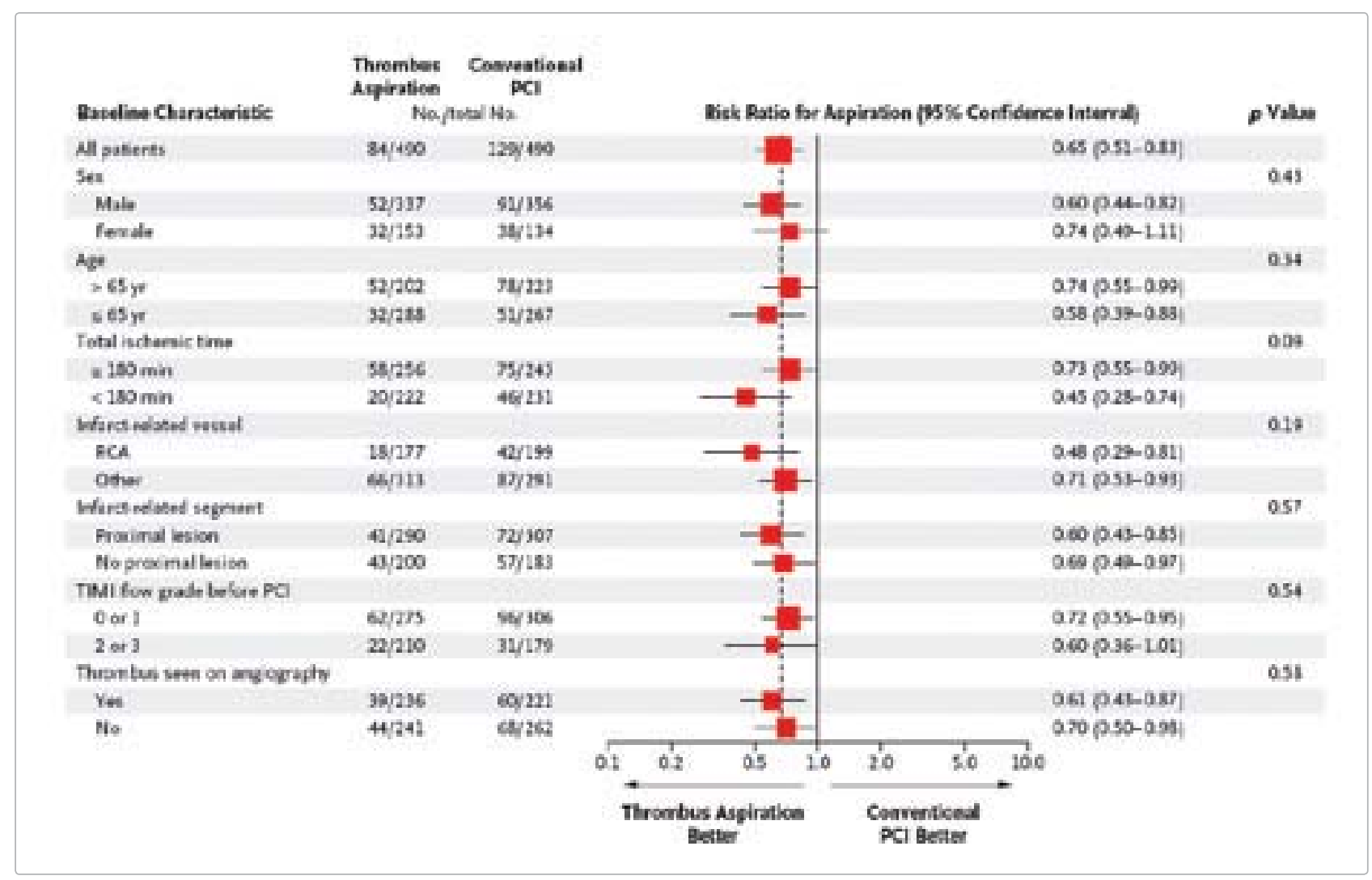

Obrázek 7 Analýza podskupin ve studii TAPAS ${ }^{(15)}$

použití mechanických trombektomů může zhoršit prognózu pacientů, zatímco systémy distální ochrany prognózu pacientů neovlivňují.

\section{Literatura}

1. DeWood MA, Spores J, Notske R, et al. Prevalence of total coronary occlusion during the early hours of transmural myocardial infarction. $N$ Engl J Med 1980;303:897-902.

2. Poli A, Fetiveau R, Vandoni P, et al. Integrated Analysis of Myocardial Blush and ST-Segment Elevation Recovery After Successful Primary Angioplasty: Real-Time Grading of Microvascular Reperfusion and Prediction of Early and Late Recovery of Left Ventricular Function. Circulation 2002;106:313-8.

3. Henriques JPS, Zijlstra F, Ottervanger JP, et al. Incidence and clinical significance of distal embolization during primary angioplasty for acute myocardial infarction. Eur Heart J 2002; 23:1112-7.

4. Fokkema ML, Vlaar PJ, Svilaas T, et al. Incidence and clinical consequences of distal embolization on the coronary angiogram after percutaneous coronary intervention for ST-elevation myocardial infarction. Eur Heart J 2009;p.ehp033.

5. De Luca G, Suryapranata H, Stone GW, et al. Abciximab as Adjunctive Therapy to Reperfusion in Acute ST-Segment Elevation Myocardial Infarction: A Meta-analysis of Randomized Trials. JAMA 2005;293:1759-65.

6. Mauri L, Cox D, Hermiller J, et al. The PROXIMAL Trial: Proximal Protection During Saphenous Vein Graft Intervention Using the Proxis Embolic Protection System: A Randomized, Prospective, Multicenter Clinical Trial. J Am Coll Cardiol 2007;50:1442-9.

7. Ali A, Cox D, Dib N, et al. Rheolytic thrombectomy with percutaneous coronary intervention for infarct size reduction in acute myocardial infarction: 30-day results from a multicenter randomized study. J Am Coll Cardiol 2006;48:244-52.

8. Lefevre T, Garcia E, Reimers B, et al. X-sizer for thrombectomy in acute myocardial infarction improves ST-segment resolution: results of the X-sizer in AMI for negligible embolization and optimal ST resolution (X AMINE ST) trial. J Am Coll Cardiol 2005:46:246-52.
9. Lipiecki J, Monzy S, Durel N, et al. Effect of thrombus aspiration on infarct size and left ventricular function in high-risk patients with acute myocardial infarction treated by percutaneous coronary intervention. Results of a prospective controlled pilot study. Am Heart J 2009;157:583.e1-.e7.

10. Sardella G, Mancone M, Nguyen BL, et al. The effect of thrombectomy on myocardial blush in primary angioplasty: the Randomized Evaluation of Thrombus Aspiration by two thrombectomy devices in acute Myocardial Infarction (RETAMI) trial. Catheter Cardiovasc Interv 2008;71:84-91.

11. Sardella G, Mancone M, Bucciarelli-Ducci C, et al. Thrombus aspiration during primary percutaneous coronary intervention improves myocardial reperfusion and reduces infarct size: the EXPIRA (thrombectomy with export catheter in infarct-related artery during primary percutaneous coronary intervention) prospective, randomized trial. J Am Coll Cardiol 2009:53:309-15.

12. De Luca G, Suryapranata H, Stone GW, Antoniucci D, Neumann FJ, Chiariello M. Adjunctive mechanical devices to prevent distal embolization in patients undergoing mechanical revascularization for acute myocardial infarction: a meta-analysis of randomized trials. Am Heart J 2007;153:343-53.

13. Kunadian B. Meta-analysis of randomized trials comparing anti-embolic devices with standard $\mathrm{PCl}$ for improving myocardial reperfusion in patients with acute myocardial infarction. Catheter Cardiovasc Interv 2007;69: 488-96.

14. Burzotta F, Testa L, Giannico F, et al. Adjunctive devices in primary or rescue PCI: A meta-analysis of randomized trials. Intern J Cardiol 2008;123:313-21.

15. Svilaas T, Vlaar PJ, van der Horst IC, et al. Thrombus Aspiration during Primary Percutaneous Coronary Intervention. N Engl J Med 2008;358: 557-67.

16. Vlaar PJ, Svilaas T, van der Horst IC, et al. Cardiac death and reinfarction after 1 year in the Thrombus Aspiration during Percutaneous coronary intervention in Acute myocardial infarction Study (TAPAS): a 1-year follow-up study. Lancet 2008;371:1915-20.

17. De Luca G, Dudek D, Sardella G, Marino P, Chevalier B, Zijlstra F. Adjunctive manual thrombectomy improves myocardial perfusion and mortality in patients undergoing primary percutaneous coronary intervention for ST-elevation myocardial infarction: a meta-analysis of randomized trials. Eur Heart J 2008;29:3002-10. 